\title{
Arachne and Athena: Towards a Different Poetics of Women's Writing
}

DOI: 10.18318/td.2017.en.2.2

I t is not easy today to say anything about the poetics of women's creativity without referring to the wellknown metaphor of text as a fabric and the figure of the weaver, practically an emblematic image of the female artist. As Kazimiera Szczuka argues in the article Spinners, Weavers, Spiders: Remarks on Works by Women, all stories of Greek spinners - Penelope, Philomela, Ariadne, or Arachne - are really about the profound analogy between the act of spinning and women's narration, language and history. ${ }^{1}$ Of course, Szczuka is here following the path of many Western second-wave feminists, who turned weaving into something more than just another writing metaphor - transforming it into a kind of founding myth of women's art, different from male creation in terms of both the inspiration and the language of expression. ${ }^{2}$ The weaving metaphor has seduced researchers of women's literature even more strongly when it revealed

1 Kazimiera Szczuka, "Prządki, tkaczki i pająki. Uwagi o twórczości kobiet," in Szczuka, Kopciuszek, Frankenstein i inne. Feminizm wobec mitu (Kraków: eFKa, 2003), 27-45.

2 For instance Marta Weigle, Spiders and Spinsters: Woman and Mythology (Albuquerque: University of New Mexico Press, 1982), Mary Daly, Gyn/Ecology (Boston: Beacon Press, 1990).

\section{Monika Świerkosz}

- Associate

Professor at the

Faculty of Polish

Studies, Jagiellonian

University. Her

interests include

contemporary critical

theory inspired

by feminism and

post-humanism and

history of women's

writing. She is the

author of the books

W przestrzeniach

tradycji [In the Spaces

of Tradition: The Prose

Works of Izabela

Filipiak and Olga

Tokarczuk in Debates

on Literature, Canon

and Feminism] (2014)

and Arachne i Atena.

Literatura, polityka

i kobiecy klasycyzm

[Arachne and Athena.

Literature, Politics and

Women's Classicism]

(2017). Contact:

monika.swierkosz@

uj.edu.pl 
its additional, non-human, one might say, meanings, and spoken about transgression. On the one hand, it referred to the divine universe over which old Parca/Moira/Clotho reigned, sitting at the loom, while on the other, it entered the microcosm of Nature, in which the animal Spider wove from her own body the thread that created the world.

It is undoubtedly also this semantic surplus that made the story of Arachne and Athena into a cultural myth, even though it may be just a poetic fairy tale, an apocryphal addition to Greek mythology invented by the Roman poet Ovid. ${ }^{3}$ This does not change the fact that the history of the contest between the Lydian weaver and the goddess related in Book VI of the Metamorphoses is an ambiguous and dark tale about art in its human and inhuman dimensions. Nancy Miller's celebrated text "Arachnologies: The Woman, the Text, and the Critic" 4 attempts to interpret the scene of Arachne's meeting with Athena from the interpretive perspective of feminist theory. Miller also exhibits the ambiguity of the trope of female authorship, the ambivalence resting in the relationship between the creator and her work, between the text and the body, and between the speaking subject and the story itself.

Yet most later commentators on Miller's article expressly emphasise what we might call the lighter side of her critical project. As Anna Burzyńska puts it:

The metaphor of Arachne has proven to be very fruitful and inspiring in feminist criticism. First, it ennobled female creative subjectivity and female sources of the writer's art. Second, it demonstrated that women's creativity is an entirely subjective act - creating a work and at the same time creating oneself. Third, it reinforced the very common tendency in feminist thought to blur the traditional dualism between subject and object established in the androcentric conception of art. Fourth, it sustained the conviction that women's creativity comes from the body, as a peculiar emanation of female corporeality. Fifth and finally, it accentuated the connection between women's creativity and daily life. ${ }^{5}$

3 Scholars are not even certain whether the story of Arachne and Athena is of Greek origin, or much later, and Roman. See A. S. Byatt, "Arachne," The Threepenny Review 78 (1999): 20-23; Sylvie Ballestra-Puech, Métamorphoses d'Arachné. L'artiste en araignée dans la littérature occidentale (Genève: Librairie Droz S.A., 2006).

4 Nancy Miller, "Arachnologies: The Woman, the Text, and the Critic," in The Poetics of Gender, ed. Nancy Miller (New York-Oxford: Columbia University Press, 1986), 270-295. Page numbers are given in parentheses within the text.

5 Anna Burzyńska, "Feminizm," in Teorie literatury XX wieku. Podręcznik, ed. Anna Burzyńska and Michał P. Markowski (Kraków: Znak, 2007), 411. If not otherwise specified all translations of referenced works are provided by the translator of the respective article. 
Arachnology, interpreted through the analogy of writing as the process of a spider weaving a web by spinning a thread from within itself, became yet another version of somatopoetics, ${ }^{6}$ which was based on a universal idea of how women create. The most important indicators of this poetic were: autobiographism (writing from oneself) and corporeality (writing oneself), and these combined to form the call to "write your self" proposed by French critics of écriture feminine.? In her book Cudzoziemki [Alienated Women], Grażyna Borkowska combines these two traditions of feminist thought: the American and the continental, with an autobiographical "disclosure" forming the foundation of women's poetics:

The story of Arachne is a vivid metaphor of women's creativity - whatever you create, you create yourself. Whatever you disclose, you disclose yourself. By writing (or creating), women lie within a constructed discourse, incapable of distance, of breaking the bonds tying them to the text, incapable of concealing themselves, of blotting themselves out and escaping. ${ }^{8}$

Borkowska also wrote Metafora drożdy [The Yeast Metaphor], one of the first Polish attempts - and still an inspirational one - to define the phenomenon of women's literature. Here, she emphasises another type of "disclosure":

We can speak of women's literature/poetry when the subject of the work discloses her gender, self-identifies herself in terms of sex. ${ }^{9}$

Of course, in our era after the "death of the author," Borkowska means "disclosure" of the author within the text, which persuades her all the more that

6 The aim of this article is not so much to challenge the category of somatopoetics as such as to show the problematic strategies for reading texts by women that result from acceptance of a reductionist means of understanding the relations between gender, the body and a text. On the limits existing in the very project of somapoetics, see "How to Embody the Body: On the Dilemma of Somatopoetics," in From Modern Theory to a Poetics of Experience, ed. Grzegorz Grochowski and Ryszard Nycz (Warszawa: Peter Lang, 2014), 271-288.

7 "Write your self - your body must be heard," urged Hélène Cixous in "The Laugh of the Medusa," trans. Keith Cohen, Paula Cohen, Signs 1 (4) (Summer, 1976): 880.

8 Grażyna Borkowska, Cudzoziemki. Studia o polskiej prozie kobiecej (Warszawa: Wydawnictwo IBL PAN, 1996), 13.

9 Borkowska, "Metafora drożdży. Co to jest literatura/poezja kobieca," in Ciało i tekst. Feminizm w literaturoznawstwie, ed. Anna Nasiłowska (Warszawa: Instytut Badań Literackich PAN, 2009), 71. 
"woman must put herself into the text,"10 identify herself in it, and then reveal this fact to readers, which is what Cixous also calls for. Borkowska sees every other (more distanced or mediated) form of constructing relations between the author and her work less as camouflage than as a manifestation of ostensible power, self-delusion placing a question mark over the authenticity of the female signature. In her writings on literary history, she often speaks of the "poetics of self-restriction," the fulfilment of a "strategy of mimicry," which, though by no means rare, mostly characterises early emancipationist writers, who adopted it in patriarchal culture, imitating the language of men."1

It is worth asking, however, whether this was how Nancy Miller understood her project - as an affirmation of somatopoetics, in which the body for the woman author becomes not so much a means of creation, but the text itself, the text as spider web.

\section{Arachne - the Headless Body}

Ovid's narrative appears clear:12 Arachne, orphaned in childhood by her mother, daughter of Idmon, a poor dyer, so skilled in weaving that she is regarded as a pupil of Athena herself, is so proud of her talent that she refuses to acknowledge her "debt" to the goddess. She even claims that she could duel with her to prove her excellence and that she is equal to Athena. Pallas is not keen on the contest, and appears in the form of an old woman to warn the mortal of the consequences of her pride, yet Arachne angrily spurns her advice. The pauper's clothes fall away, and Athena is already sitting at the looms and weaving a tapestry: in the centre, she places images of the rulers of Olympus, and in the four corners, scenes symbolically representing the tragic fates of those who wished to match the gods. The whole thing is bordered by an olive branch of peace. Arachne, meanwhile, presents mortals: Leda, Europa, Antiope, Danae, Proserpine, Medusa - all of them led astray insidiously by the gods, and mostly by Athena's father Zeus. "A real bull you'd think, / And real sea" (124), to each the girl "gave their own / Features and proper features of the scene" (124), finally surrounding everything with a narrow band of ivy and flowers. Ovid has no doubt that this marvellous work by her rival makes Athena jealous. The incensed goddess tears up her tapestry, and strikes Arachne herself

10 Cixous, "The Laugh," 875.

11 Borkowska, Cudzoziemki, 180.

12 Ovid, Metamorphoses, trans. A. D. Melville, introduction and notes E. ). Kenney (Oxford: Oxford University Press, 1987). All quotations from this edition; hereafter page numbers are given in parentheses within the text. 
several times on the head with the boxwood shuttle. The disgraced mortal tries to hang herself, yet the goddess takes pity, and turns her into a spider.

"Live!" she said, / "Yes, live but hand, you wicked girl, and know / You'll rue the future too: that penalty / Your kind shall pay to all posterity!" / And as she turned to go, she sprinkled her / With drugs of Hecate, and in a trice, / Touched by the bitter lotion, all her hair / Falls off and with it go her nose and ears. / Her head shrinks tiny' her whole body's small; / Instead of legs slim fingers line her sides. / The rest is belly; yet from that she sends / A fine-spun thread and, as a spider, still / Weaving her web, pursues her former skill. (125)

According to Miller, this is a story about institutionalised violence in which topics of gender, politics, and art are interspersed. There is also no doubt that this transformation of the weaver into a spider has nothing affirmative about it, but is a form of repression and degradation, because it results in the woman's creative energy being imprisoned inside the body of an arachnid. For her tapestry-protest, Arachne is punished by the removal of her head and being pushed to the limits of "femininity" - from now on, she is "restricted to spinning outside representation, to a reproduction that turns back on itself. Cut off from the work of art, she spins like a woman." (274)

Like a woman, but not like an artist - this is a surprising statement, problematic from a feminist perspective. It runs alarmingly close to the misogynous stereotype of the female author so convincingly reconstructed by Krystyna Kłosińska in her analysis of the recurring images and tropes in the statements of nineteenth-century literary critics: women writers are "spinners of banal reality," "literary weepers," and "cows grazing on gossip."13

Yet Miller is consistent: throughout her article, a key role is played by the differentiation between weaving, that is the artistic production of pictures, and spinning, that is a mute lamentation unable to present and at the same time unrepresentable. The former model of women's expression is represented by Arachne, but before her transformation, and the latter by Ariadne, "a figure of the feminine other created by masculinity" (270), who is unable to escape the role of being a victim culture ascribes to her. But "Arachnologies" is not about a direct juxtaposition of these two female figures: in relating the histories of two mortal women beguiled and abandoned by gods, Arachne ultimately creates her tapestry for Ariadne too, so that her traumatic experience finally receives its narrative form.

13 Krystyna Kłosińska, "Kobieta autorka," in Ciało i tekst. Feminizm w literaturoznawstwie, 94-116. 
Nevertheless, Miller is opposed to affirming Arachne's headless spider form. She regards flirting, as she puts it, with "an aesthetics of the decentered (in fact decapitated) head" (274), as the amusement of a subject who has already read herself, and in culture constantly experiences the Barthesian effect of déjà lu. And yet, when we enter the sphere of women's output, "underreading" continues to apply, as the pictures created by women still seem like representations without a cultural framework. This is what Miller is searching for in the signature that both Athena and Arachne leave on their tapestries. So it is not so much about some kind of resuscitation of the Cartesian subject slayed by Barthes, understood as the author's extratextual, psychobiological instance, but rather about going beyond the opposition of internal and external, joining together in the act of interpretation of the cultural and the textual, the public and the personal, what is in the centre of the image and its edges. Only then will it be possible to discern the splice of politics, aesthetics, and autobiography that interests Miller, as well as to historicise the authorial signature. Reflecting upon the question of the material nature of a literary text, the critic is not satisfied with delighting in the beauty of the spider's web, but also looks at the place where reality begins to shine through. Here, she is clearly following the path of Virginia Woolf, who in A Room of One's Own also used the metaphor of literature as a spider's web, while also pointing out the rather unmetaphorical senses that it conceals.

[...] when the web is pulled askew, hooked up at the edge, torn in the middle, one remembers that these webs are not spun in mid-air by incorporeal creatures, but are the work of suffering human beings, and are attached to grossly material things, like health and money and the houses we live in. ${ }^{14}$

Contrary to the deconstructionists - Roland Barthes, Geoffrey Hartman, and Joseph Hillis Miller who elected to examine the fabric woven, rather than listening to the story of the weaver ${ }^{15}$ - the author of "Arachnologies" wants to

14 Virginia Woolf, A Room of One's Own (London: Penguin Classics, 2002), 43.

15 Apart from Barthes's very well-known books (The Pleasure of the Text and S/Z), in which the metaphor of text as fabric appears, Nancy Miller disputes the interpretations of the deconstructionists, referring to the weavers themselves: Ariadne, Penelope, and Arachne. She cites Joseph Hillis Miller, "Ariadne's Broken Woof," Georgia Review 31 (1997); Geoffrey Hartman, "The Voice of Shuttle: Language from the Point of View of Literature," in Hartman, Beyond Formalism: Literary Essays, 1958-1970 (New Haven: Yale University Press, 1970). She allows us to track the places in the text in which the interpretive paths of feminism and deconstruction diverge. Miller, an ardent structuralist and poststructuralist at the same time, comments upon this dissonance with ironic truculence: "Philology makes odd bedfellows" (Miller, "Arachnologies," 285). 
read "against the weave of indifferentiation to discover the embodiment in writing of a gendered subjectivity" (272). Yet at the same time, contrary to theoreticians of écriture féminine, she is interested not in the "corporeality of a female text," but in the authorial subjectivity embodied in the text and still understood in personal terms. ${ }^{\mathbf{1 6}}$ Finding this will only be possible when we face up to the seductive force of both the Ovidian narrative and deconstructive theories, which emphasise the importance of the spider's web and spider rather than the punished artist. This is why Miller understands arachnology not in terms of a postmodern neologism, but as a catachresis that is here an expansion (or perhaps an abuse, as the Greek etymology of the word states) of the meaning of an existing word, now shifted into the field of interpretation theory. A catachresis fills the gaps in the dictionary - creating analogies without which certain areas of reality would remain unnamed. The body plays a considerable role in such cases, as in the phrases "foot of the mountains" or the "lip of a cup," which do not have any other, non-metaphorical equivalents in the language. This is an entirely different "necessity" from that ingrained in the plot of a myth, or that which Grażyna Borkowska had in mind when she wrote of women's inability to escape from their own body-text. Just like Halina Filipowicz, who in her article Against "Women's Literature"17 recalls the misogynistic, anti-women approach of this "epithet" of literary criticism that the term "women's literature" was in the past, Nancy Miller warns of enclosing the interpretation of women's writing within the poetics of the "headless body" imposed on women (as culturally appropriate to them).

To remember Arachne only as the spider, or through the dangers of her web alone, is to retain the archetype and dismember, once again, with Athena, the subject of its history: to underread. (288)

She tries to contradict this herself, touching the place in which the spider became attached to its web and thus emphasising the connection between

16 It was no coincidence that in the 1990s, and thus during the autobiographical boom, Miller published the collection of feminist essays Getting Personal, developing a further critical project named personal criticism. This was again an attempt to create her own theory of the personal, which may, but does not have to, overlap with the category of the autobiographical. On the dissonance between French theories and arachnology, as well as the personal criticism project, see Krystyna Kłosińska, "Między esencjalizmem a dekonstrukcją: Nancy Miller" ["Between Essentialism and Deconstruction: Nancy Miller"], in Miller, Feministyczna krytyka literacka [Feminist Literary Criticism] (Katowice: Wydawnictwo UŚ, 2010), 299-356

17 Halina Filipowicz, Przeciw literaturze kobiecej, in Ciało i tekst. Feminizm w literaturoznawstwie, 222-234. 
power - gender - and representation. She believes that this, as she puts it, "topographic" reading will make it possible to "attach meaning to this female fable" (270), restoring Arachne's voice from before the transformation: Arachne the weaver, Arachne the artist.

Miller recommends an interpretative "overreading" of "underread" places. Embracing this challenge, I reread "Arachnologies," Ovid's poem, and also various feminist commentaries of the story that I know as if I were doing so for the first time. I was rather surprised to learn that one more "underread" place in the myth is the figure of Athena: her tapestry and her signature left on it. So who is Athena in feminist investigations on women's mythology of creation and women's poetics?

\section{Athena - the Bodiless Head}

Themythology that underlies patriarchy has not changed. Everything described in the Oresteia is still taking place. Here and there we still see the emergence of some useful Athenas, who spring whole from the brain of the Father-King, dedicated solely to his service and that of the men in power. They bury the women who fight patriarchy under the sanctuary so as to eliminate any troublesome challenge to the new order laid down for households, the order of the city-state, the only order from now on. These useful Athenas, perfect models of femininity, always veiled and clothed from head to toe, very respectable, can be recognized by this sign: they are extraordinarily attractive - which doesn't mean they attract - but they really aren't interested in making love. ${ }^{\mathbf{1 8}}$

The "phallic woman," "guardian of the patriarchate," pseudo-woman, daughter-law; ${ }^{\mathbf{1 9}}$ undoubtedly, Athena is an antiheroine of feminist critique, a bad sister who betrayed the female community. Although Nancy Miller seems to discern the ambivalence lying in the very figure of the goddess, whose attributes are a shield and helmet, but also a spindle, in the end she deliberately chooses not to reinterpret her. ${ }^{20}$ She writes about her in categorical terms: "Thus, outwomaned,

18 Luce Irigaray, "Body against Body: In Relation to the Mother," in Sexes and Genealogies, trans. G. C. Gill (New York: Columbia University Press, 1993), 12-13.

19 Gayatri Chakravorty Spivak, "Displacement and the Discourse of Woman," in Displacement: Derrida and After, ed. Mark Krupnick (Bloomington: Indiana University Press, 1983). I have not tried to answer in this paper. Nor have I discussed the ways in which this is a story [...] that takes place between women" (p. 290). 
and in phallic identification with Olympian authority, the goddess destroys the woman's countercultural account: she »rent the embroidered web with its heavenly crimes «" (273). According to Miller, Pallas is symbolically stripped of a body, because she "identifies not only with the gods, but with godhead, the cerebral male identity that bypasses the female" (273). Whereas the critic uses the Arachne-Ariadne pairing to explain the difference between a rebellious, creative woman weaver with her own voice and the "female victim," seduced and abandoned by a man, embodying the male fantasy of womanhood, the opposition between Athena and Arachne seems even too obvious. Athena, "covered from head to toe," is paradoxically transparent, and clearly removed from gender concerns - she creates her tapestry and leaves her signature on it, yet this does not find an interpreter. This is not because the goddess produces her work in a different way from Arachne. On the contrary, both seem to represent the same "workshop" approach to art understood in terms of techne rather than ars. This is also not entirely clear in Ovid's narrative, but we can conjecture that, whereas Athena prefers a more enigmatic narrative of "symbolic signs," Arachne used realistic images to express herself. Yet this is not enough to compare these two types of creativity, which is why Miller - unlike Cixous, Irigaray, and Kristeva, or also Borkowska, following their lead - does not concentrate on the formal differences of language or style. The actual difference between the protagonists' tapestries concerns the sphere of representation and the question of rebellion the goddess's fabric is a theocentric depiction of repressive power, which in the name of order disciplines impudent rebels, while Arachne's work is a femalecentric protest against the authorised abuses of this power. And since in this interpretation (as in many feminist theories of subversiveness), only that which is anti-phallogocentric is defined as female, ${ }^{\mathbf{2 1}}$ Athena is condemned to exile beyond the borders of her own sex, and becomes a symbolic "man." From now on, she will be treated as a "masquerader" in a truly female world, a false woman, one with a man's head.

The Gallant Maiden, born from the head of her father and with no mother, does not feel closeness and solidarity with other women - like in Aeschylus' Oresteia - she is closer to the brutal, harsh, and rational world of men, heroes, and rulers. Circumspect yet wrathful, ambitious but also obstinate, proud and ruthless. What might be a possible definition of the art that Athena would

21 For many scholars, identifying womanhood with anti-phallogocentricity or anti-patriarchalism became a foundation of women's writing theory. I will only mention Cixous's words: "A feminine text cannot fail to be more than subversive. It is volcanic; as it is written it brings about an upheaval of the old property crust, carrier of masculine investments; there's no other way. There's no room for her if she's not a he. If she's a her-she, it's in order to smash everything, to shatter the framework of institutions, to blow up the law, to break up the 'truth' with laughter." Cixous, "The Laugh," 888. 
patronise? Perhaps one that is rational; a record of cool intellectual analysis of an object rather than testimony of a subjective experience; formally perfect, but lacking in feelings; contemptuously turned away from petty, mundane affairs; asexual? Certainly, it would not fit within the limits of somatopoetics.

And yet this interpretation of the myth seems to me to be too simplistic, falling apart in a place that is crucial for feminist critics - the patriarchal origin of Athena's birth. After all, Hesiod in Theogony also mentions her mother Metis, the pre-Olympian goddess of wisdom and justice, in the oldest tales also known in the form of the snake-haired Medusa, whom Zeus devoured when she was pregnant. In the subsequent, later texts of the post-Homeric era, however, the traces of this matriarchal genealogy are blurred. All that remain are individual symbols entwined in patriarchal narratives - Pallas' epithet "poly-metis" ("giving much advice"), the snake lying at her feet, the head of Medusa on her shield and a set of incoherent characteristics.

If Athena was the armed and ferocious god of war, then why did the Greeks regard her as a defender of the betrayed and the maker of the most important rules in her world protecting the weak? Even the rather uninquisitive Jan Parandowski noticed this flaw of inconsistency in the monumental depiction of Athena, citing her commandment:

Do not deny anyone water or fire. Do not show a false path. Do not leave a body unburied. Do not kill an ox leading a plough.22

If the goddess was supposed to be the embodiment of male virtues, why was she also the greatest teacher of women's work and art - weaving, pottery, cooking - and also a carer for those giving birth? Pronaia, Ergane, Polias, Promachos, Parthenos, Pallas, Hygieia - whatever name she is given, she eludes explicit (let's call it patriarchal) symbolism. Following the research of Jane Ellen Harrison, Robert Graves in The Greek Myths writes of Athena as a combination of two embodiments of the matriarchal goddess triad - the awe-inspiring old woman and the maiden.

J. E. Harrison rightly described the story of Athene's birth from Zeus's head as "a desperate theological expedient to rid her of her matriarchal conditions." It is also a dogmatic insistence on wisdom as a male prerogative; hitherto the goddess alone had been wise. ${ }^{23}$

22 Jan Parandowski, Mitologia. Wierzenia i podania Greków i Rzymian (Londyn: Puls, 1992), 64.

23 Robert Graves, The Greek Myths: The Complete and Definitive Edition (London: Penguin, 2011 [1955]), 46. It is interesting, as well as somewhat alarming, that Athena was restored to the feminist imaginarium, so to speak, not by the works of Graves or Harrington, but 
The reason I mention this displaced, motherly genealogy of the mythological Athena is not only to show "how it really was," but to avoid being led astray by the seductive power of all myths and mythologies, which turn history into nature, take an effect as a cause, and explain what was by what is. In the case of Arachne's story, it may well be that some feminist commentators believed too much in the patriarchal fairy tales of the bad sister, with the result that Athena the spinner and her tapestry vanished completely from the feminist imaginarium, and with it the admittedly problematic, but important questions about women's involvement in the patriarchy and the structures of power. On Athena's tapestry, punishment for impertinent mortals is handed out by Hera - another "phallic woman"? Is feminism today really incapable of a more complex analysis of the relations of gender and power? And by this I do not mean ignoring the difference between the two tapestries, replacing Arachne's story with that of Athena, or nullifying questions about the link between ethics and aesthetics, but rather the normative way of understanding the category of womanhood, used (even today) to discipline women.

This is an interesting track insofar as feminist critique is continuing to struggle with methodological problems: how should we read those texts of women which take the side of reason, and not the body, and do not fulfil the model of somatic writing regarded as culturally feminine or are not different from the male means of expression, in either form or content? Does a text with a traditional, non-avant-garde form, by a female writer not tackling so-called women's, emancipationist subjects, automatically become a non-feminist text, meaning non-womanly, that is patriarchal text? ${ }^{24}$ Do classically oriented female authors who are intellectually distanced from their textual "I," or opt for avant-garde experiment over autobiographism, falsify their experience as women, have a problem with their identity, and become suppressed victims of patriarchal schizophrenia, or do they bolster themselves by donning men's hats and speaking in the voice of others? ${ }^{25}$

by Camille Paglia, a pupil of Harold Bloom, who describes herself as the "anti-feminist feminist." See Camille Paglia, Sexual Personae: Art and Decadence from Nefertiti to Emily Dickinson (New Haven: Yale University Press, 1990), 80-86.

I mention this sequence of identifications not because I consider these concepts to be identical, but to illustrate the way of thinking about the relations between a women's text and patriarchal culture that continues to be present in feminist practices. See Małgorzata Büthner-Zawadzka, Warszawa woczach pisarek. Obraz i doświadczenie miasta w polskiej prozie kobiecej 1864-1939 (Warszawa: Wydawnictwo IBL PAN, 2014). 
Since the 1980s, researchers of women's literature have been trying to grasp the problem of the dual coding of women's literature in tradition, which is manifested in, as Elaine Showalter put it, the double-voiced nature of women's text, and according to Sandra Gilbert and Susan Gubar, the female affiliation complex. ${ }^{\mathbf{2 6}}$ It is crucial in both questions to ascertain the places where the heritage of the "mother" and the "father" intersect, cross or come into conflict. The figure of Athena - as a peculiar incarnation of this ambivalence - might tell us something interesting about the cultural place of the woman author in tradition, but also about how women function within diverse institutions of power. ${ }^{\mathbf{2 7}}$

Nevertheless, it seems necessary to me to tackle these questions today, not only because of the increasingly restrictive modes of feminist reading and the still excessively predictable canon of texts that female researchers wish to explore, but also on account of the strategy, well known to critics and historians, of erasing gender and "attaching" male heads to those women writers who manage to enter the canon. Denied their womanhood, turned into honest "literary aunts," unread and gathering dust, wheeled out only for special jubilees, their anachronistic nature puts readers off. Orzeszkowa, Konopnicka, Przybyszewska, Dąbrowska. Must it be thus?

\section{Maria Dąbrowska - Corrected Biography, Corrected Works}

That vaguely cross-eyed little dwarf, with her mane cut pageboy style, was the last creature on whom I could focus my erotic passions. I knew

niewieści albo przerost stylu" ["The Clamour of the Womanly or the Excess of Style"], Stanisława Przybyszewska (as a proponent of the idea of asexual, non-gendered writing), Maria Dąbrowska (as a national writer-institution) and Anna Bojarska (as an author of political romances and the collection Madonna pekaesów, czyli wyznania czytelnika-samicy [The Commuting Madonna, or Confessions of a Female Reader]).

26 See Joanna Krajewska, "»Kobiecy kompleks przynależności« i historia literatury" ["»The Feminine Complex of Belonging" and Literary History"], in Fifteen Shades of Polish Feminism: Literature, Culture and Gender Discourses in Polish Academia. Women Online Writing Journal 3 (2014), ed. Urszula Chowaniec, Monika Świerkosz, http://www.womenonlinewriting.org/issue-no-3-history-of-polish-feminism-in-academia-in-polish.html, accessed July 11, 2015.

27 Nancy Miller quotes Mary Jacobus in Reading Woman, arguing: "Like Lucy Snowe and Charlotte Brontë, a feminist critic is »bound, if she is to gain both a living and a hearing, to install herself within the prevailing conventions of academic literary criticism «" (270). This is complicated (fortunately!) by thinking about the anti-system tendencies of feminism and feminist critique within patriarchal power structures. 
nothing about what would eventually become general knowledge among the readers of her diaries, that is, about her erotic side, so to speak. ${ }^{\mathbf{2 8}}$

This was how Czesław Miłosz described his fellow writer, making direct allusions to the deficits of womanhood that rendered him incapable of looking at her as a female being. She seems so extremely asexual to him that she is completely lacking in gender - like a child or a dwarf. Grażyna Borkowska tones down these words only slightly in her book about Dąbrowska and Stanisław Stempowski.

In her ordinary modest male clothing she does not look very feminine.

She resembles a young lad rather than an attractive woman. ${ }^{29}$

Later, she stresses the writer's aversion to make-up, fashionable outfits, caps, hats and all the trappings of femininity popular in the inter-war period. Indeed, in her sporty costumes Dąbrowska does seem to differ from the cultural model of womanhood represented, for instance, by Zofia Nałkowska. This is also visible in her first attempts at literary criticism, in which she distances herself from heroines embodying the type of passive, feeble, society femininity, calling them "faunesses," "lacy," "pretty waifs made of Majolica," "little dolls with hearts made of biscuit fin," "swung by male lust and their own whim." ${ }^{30}$ Dąbrowska also does not consent to the tragic fate and sacrifice of Stefan Żeromski's female protagonists. She is evidently searching in literary tradition for a paragon of female strength and agency.

Her position regarding her own corporeality, sexuality, and gender - which can be reconstructed on the basis of her Diaries - is affirmative. She is happy with herself: she is shapely, lithe, she likes her body, exercises, washes in cold water, likes to sun herself and bathe nude in summer, and is a passionate ice skater in winter. Until the end of her life she enjoys receiving compliments from those close to her and strangers about her legs, bust, hairstyle, clothes, and even hygiene (a lady selling towels in devastated post-war Warsaw: "You're a real Mrs. Clean"), and responds positively to the wooing of men she

28 Czesław Miłosz, Milosz's ABC's, trans. M. G. Levine (New York: Farrar, Straus and Giroux, 2001), 94 .

Grażyna Borkowska, Maria Dąbrowska i Stanisław Stempowski (Kraków: Wydawnictwo Literackie, 1999), 58. nesses], and her review of Żeromski's The Faithful River. See Maria Dąbrowska, Pisma rozproszone [Scattered Writings], vol. 1, ed. Ewa Korzeniewska (Kraków: Wydawnictwo Literackie, 1964), 36, 46. 
meets. In fact, even in her old age Dąbrowska accentuates her vitality, attractiveness, and strength - as a woman, one might add, since she perceives herself in accordance with her gender, not outside of it. Within this image there is also sexuality, treated as a natural life energy that eludes "social" or "cultural" precepts. For her whole life, she was fascinated by both men and women, and sex evidently brought her pleasure since she confides in a friend in a letter from 1933 with unconcealed regret: "Celibate for a year, the first time since I was eighteen." ${ }^{31}$ Dąbrowska had lovers of both sexes, and more than once in the Diaries she underlined the relationship between writing and loving, between creativity and sexuality, although - perhaps unlike Nałkowska - she also discerned the negative side of this connection and the various contradictions of such a philosophy of artistic creation (and life).

What in fact happened was that first critics and then literary historians had a problem with the image, full of cracks and inner contradictions, of the writer, whose personal life became the subject of much speculation, insinuations, or overt gossip. There was conjecture as to the reasons for what Miłosz called her "erotic side," and what Borkowska saw as the dissonance between the ethical and erotic side of her work, and there were various attempts to justify, understand, explain, ${ }^{32}$ or even exploit it. Błażej Warkocki mentions the widespread supposition that the writer's support for the communist authorities was related to her "disordered erotic life," to which she had become something of a hostage. ${ }^{33}$

As a result of all this, Dąbrowska's biography was subject to constant revisions. One way in which this was expressed is, I would argue, the nullification of her relationships - the intellectual ones, friendships and love affairs - with women, who, unlike in the case of the writer's male partners Marian Dąbrowski, Stanisław Stempowski and his son Jerzy, and even her lover Jerzy Czop - are actually "underread." As a result, scholars usually regard Dąbrowska as an "Athena springing from the head of Zeus," an "eternal pupil of her men," who shaped her as a woman and a writer. Indeed, she

$$
\begin{aligned}
& \text { Btace } \\
& \text { pocis } \\
& \text { the }
\end{aligned}
$$
Warkocki is probably alluding to Wiesław Paweł Szymański’s article "Maria Dąbrowska uroki dworu" [Maria Dąbrowska - Charms of the Manor House], Arka 42 (1992): 42, 25-48, which was critical of Dąbrowska the communist. 
often spoke of the invigorating influence of male company, but at the same time she said much about her friendships not only with Anna Kowalska or Stanisława Blumenfeld, but also Zofia Nałkowska, Zofia Poniatowska, Stefania Stempołowska, Kazimierz Muszałówna, Wanda Kociełło, as well as her sister Jadwiga and mother Ludomir Gałczyńska Szumska. Historians (even those sensitive to gender issues) have done much to erase or neutralise the controversies concerning the homosexual aspect of some of these relationships.

Of course, such behaviour is certainly related to certain unspecified bisexual predispositions, but in itself it was not to do with any perversion. On the contrary, in its naturalness, its instinctive following of the voice of the heart or body, it was utterly innocent, almost childlike. ${ }^{34}$

For some, then, a lascivious, erotic side, and for others a childlike innocence it would appear that historians and critics lack a language to describe the fractured internal tensions and inconsistencies in the biography of the writer, who was awarded canonical status in schools. Towards the end of her life, Dąbrowska herself became irritated by this dual image - reverential and yet infantile - that professors of Polish literature created for use in school readers and on the occasion of jubilees. In her Diary, she gives a sarcastic account of a conversation with one such professor, Zdzisław Libera.

You make me so virtuous, you turn me into a moralising old aunt, please allow me to be unvirtuous.

"Well, it's hard to demonise," he answered [...], and that was the most intelligent thing I heard from that professor. ${ }^{35}$

Dąbrowska was fully aware that her own biography also had idiosyncratic places; in her private notes, she saw these as a dialectic of nocturnal and diurnal thoughts. She openly admitted that she frequently did not recognise herself in them, since in her life she had often succumbed to various influences that caused an incessant and irremovable discord between experience and representation. And yet she was willing to accept this, since she confidently added:

Borkowska, Maria Dq̨browska i Stanisław Stempowski, 121. [Journals 1914-1966 in 13 Volumes: The First Full Edition in 13 Volumes], vol. 13 (Warszawa: Wydawnictwo PAN, 2009), 69. Except for footnote 42, all quotations come from this edition: hereafter page numbers are given in parentheses at the end of quotations. 
[...] I was loath to correct a text written some time ago in the opaque sense that this "otherwise" was also a kind of truth bearing witness about myself and about my life. (vol. 3, 127)

While Anna Kowalska, the first reader of Dąbrowska's diaries, accused her of falsehood and distortion of reality, ${ }^{36}$ the writer herself left many furrows, wrinkles and rough patches in her image, as she believed strongly in the multiple truths of a diary, abandoning the simple opposition between authenticity and forgery. Unlike Dąbrowska, her readers and critics seem unable to believe her words, cleansing her biography of the particularly worrying places of ambivalence or interpreting them as a sign of inconsistency, and even hypocrisy. In 1935, the writer noted with regret that her relationship with the much older Stempowski was gradually depriving her of her youthful energy and vitality, and had enclosed her life within his family matters and social contacts. Borkowska is perplexed, asking "How might one explain these bitter, rather unfair and rather untrue words?", before concluding that "there is not much sense in this, there is pity and misunderstanding." ${ }^{37}$ The scholar also found it impossible that Dąbrowska could regret her wasted youth spent at Stempowski's side, while to the same degree treasuring and loving him.

This strategy of revision is also clearly manifested in the reception of her works, especially Nights and Days, her most important work. Tadeusz Drewnowski, ${ }^{38}$ like most interpreters of the novel, considers its main psychological-moral theme to be "Barbara's coming to terms with Bogumił's attitude," and argues that Dąbrowska "relishes ridiculing and belittling Barbara

36 I wrote about this in the paper "Atena i Arachne? Anna Kowalska i Maria Dąbrowska we wzajemnej lekturze dzienników" ["Athena and Arachne? Anna Kowalska and Maria Dąbrowska in a Mutual Reading of Diaries"], given at the conference Czytanie... Kobieta, biblioteka, lektura [Studying... Woman, Library, Reading], held at the University of Szczecin on 23-24 April 2015 - the article is to be published in the post-conference proceedings.

Borkowska, Maria Dąbrowska i Stanisław Stempowski, 112-113.

38 I appreciate the enormous work done by Tadeusz Drewnowski, who as editor of Dąbrowska's diaries and author of Wyprowadzka z czyśćca [Moving out from Purgatory] attempted to problematise the image of the author, criticised after 1989 for anachronism, anticlericalism, provinciality and political conformism. As for the issues of gender that interest me, however, Drewnowski admits that he is insufficiently sensitive and attentive; see Tadeusz Drewnowski, "Nie tylko odpoczciwiona (z Tadeuszem Drewnowskim rozmawia Elżbieta Sawicka)" ["Not only Rested: Eliżbieta Sawicka in conversation with Tadeusz Drewnowski"], in Wyprowadzka z czyśćca. Burzliwe życie pośmiertne Marii Dąbrowskiej [Moving out of Purgatory: The Story Posthumous Life of Maria Dąbrowska] (Warszawa: PIW, 2006), 111. 
at every step." 39 In 1960, during the ceremony at which Dąbrowska was awarded the title of honoris causa at the University of Warsaw, Julian Krzyżanowski called the heroine of Nights and Days a "shrew," an opinion that Drewnowski sees as legitimate, albeit inelegantly expressed.

In her Diaries, Dąbrowska made no secret of her indignation at this.

To say that one reads the novel engrossed, in spite of the unlikable shrew Barbara, would be a scandal for an ordinary reader, but for a literature professor, it's a multi-level scandal!

To think that it mainly was for this character, for Barbara, that the novel came about. (vol. 12, 40-41)

Dąbrowska tried, unsuccessfully, to win equal treatment for the character of Barbara in her novel, and rued the fact that no one but Zofia Nałkowska and a few foreigners discerned the significance and innovativeness of this literary heroine. This leads her to comment in the Diaries on an interpretation of Nights and Days by Stefan Gołębiewski, a school teacher from Bieżum - an interpretation that she had stumbled upon:

He noticed Barbara! No critic or historian has ever been interested in Barbara, although the whole novel rests on her. Barbara is the mother of our time. She is the element of night in Nights and Days. The prototype of all (or one of them) who are alienated, questioning and suspicious of life, its meaning, value and safety. If I myself treat her with a touch of irony and distance, that is to protect myself from showing excessive solidarity with her unease. (vol. 12, 208)

Interestingly, Drewnowski quotes the very same passage from the Diaries in his book Rzecz russowska [The Russów Matter], and quickly nullifies the writer's voice, correcting, so to speak, a possible reading of her work.

But these interpretations have their limits, and it is impossible to go so far - as the author later imagined it - as to make Ms. Barbara the catastrophist the mainstay of the novel. From such an angle, Nights and Days would turn to dust. ${ }^{40}$

39 Tadeusz Drewnowski, Rzecz russowska. O pisarstwie Marii Dąbrowskiej (Kraków: Wydawnictwo Literackie, 1981), 201. 
Grażyna Borkowska, meanwhile, expresses the difference between Nałkowska's and Dąbrowska's diaries by picturing them as two opposites functioning as contradictions of each other. And so, whereas Nałkowska writes (as a woman) "herself and from herself," effacing the boundary between life and art and gladly reaching for the boundless resources of her energy as a woman, "Dąbrowska is the suicide-writer type, conflicted with the material of her art, experiencing an ambivalent sensation of love and hatred for her work. Everything she writes comes in an incredible tension and physical effort. She writes in pain [...]. She squeezes out every last drop."41 Arachne and Athena?

This model of reading, in which Dąbrowska's writing is compared in radical terms with that of other (by implication more feminine) authors is still exercised by historians trying to describe her indeed difficult and complex - in its personal and literary dimension - relationship with Anna Kowalska. Yet it is worth listening to the voice of the writer herself, who conceived her need to be different as a positive. When a literary critic responded to the publication of Nights and Days by comparing her to Zofia Nałkowska, Dąbrowska readily concurred with a friend's verdict that, whereas "Ms Zofia sews her things ornately from costly and real silk," she "chisels granite." None the less, she immediately added, this did not change the fact that for all these differences she regarded the other woman as "alongside Colette and Undset, the greatest female writer of our time." ${ }^{2}$ So there is room here both for somebody else's differentness and for the need for recognition of one's own literary autonomy. Rather, then, than juxtaposing the literary Athenas and Arachnes as deadly rivals, let us try to describe their art from the perspective of a continuum in terms of literary history, but also poetology, which, in the case of women authors, remains to be fully studied in Poland. ${ }^{43}$

The final word should go to Maria Dąbrowska, who remains the mistress of piling up complications, and who, like Barbara Niechcic, used the language of dreams to tell of her deepest concerns:

On the verge of night, around 12, I fell asleep with the light on. A nightmare - I want to get to the telephone and get tangled in a web of copper

41 Borkowska, Cudzoziemki, 245.

Dąbrowska, Dzienniki [Diaries] (six-volume edition), ed. Tadeusz Drewnowski, vol. 1 (Warszawa: Czytelnik, 1988), 308-309.

43 The call for a return to "poetological" research in Polish gender studies was made by Arleta Galant, who placed it within a broader cultural turn in literary history. See Arleta Galant, "Feministycznie o historii literatury i zwrocie kulturowym. Przypisy do dwóch projektów" ["Feministically on Literary History and the Cultural Turning: Footnotes for Two Projects"], in Fifteen Shades of Polish Feminism. 
wires - No way to untangle myself - in the end I pull copper wires out of myself, and then, as if from the old "seal" fur I'm wearing - I pull out various crumpled things - including the lining of the grey fur - Horror How did that get in me? Did I steal it? - I want to throw the fur lining in the fire - Anna doesn't give it to me - Anna, who doesn't look like Anna, but like the New York Statue of Libery - hard, cold and powerful - only her smile is alive, but unpleasantly meaningful - attempts to embrace and kiss me, seeing that I'm distracted and decomposed - Every touch causes me unbearable pain - everything hurts acutely, even my chin, which she touches with her finger. I cry in fear: "It hurts - Everything hurts terribly." (vol. 13, 240)

Translation: Benjamin Koschalka 